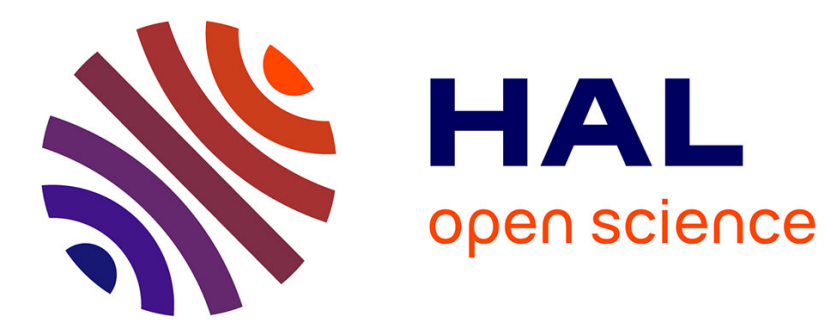

\title{
Taking advantage of ortho- and peri-substitution to design nine-membered P,O,Si-heterocycles
}

Thomas Delouche, Elsa Caytan, Cassandre Quinton, Thierry Roisnel, Marie Cordier, Vincent Dorcet, Muriel Hissler, Pierre-Antoine Bouit

\section{To cite this version:}

Thomas Delouche, Elsa Caytan, Cassandre Quinton, Thierry Roisnel, Marie Cordier, et al.. Taking advantage of ortho- and peri-substitution to design nine-membered P,O,Si-heterocycles. Chemistry A European Journal, 2021, 27 (44), pp.11391-11397. 10.1002/chem.202101184 . hal-03244130

\section{HAL Id: hal-03244130 \\ https://hal.science/hal-03244130}

Submitted on 1 Jun 2021

HAL is a multi-disciplinary open access archive for the deposit and dissemination of scientific research documents, whether they are published or not. The documents may come from teaching and research institutions in France or abroad, or from public or private research centers.
L'archive ouverte pluridisciplinaire HAL, est destinée au dépôt et à la diffusion de documents scientifiques de niveau recherche, publiés ou non, émanant des établissements d'enseignement et de recherche français ou étrangers, des laboratoires publics ou privés. 


\title{
Taking Advantage of Ortho- and Peri-substitution to Design Nine-membered P,O,Si-heterocycles
}

\author{
Thomas Delouche, ${ }^{[a]}$ Elsa Caytan, ${ }^{[a]}$ Cassandre Quinton, ${ }^{[a]}$ Thierry Roisnel, ${ }^{[a]}$ Marie Cordier, ${ }^{[a]}$ Vincent Dorcet, ${ }^{[a]}$ \\ Muriel Hissler, ${ }^{[a]}$ and Pierre-Antoine Bouit*,[a] \\ [a] Dr T. Delouche, Dr E. Caytan, Dr C. Quinton, Dr T. Roisnel, M. Cordier, Dr V. Dorcet, Pr M. Hissler, Dr P.-A. Bouit \\ Univ Rennes, CNRS, ISCR - UMR 6226, F-35000 Rennes. \\ E-mail : pierre-antoine.bouit@univ-rennes1.fr
}

\begin{abstract}
A family of cyclic phosphine-disiloxane featuring peri-substituted naphthyl(Nap)/acenaphthyl(Ace) scaffolds has been prepared and fully characterized including X-ray structure, which enables a detailed structural analysis. This straightforward synthesis takes advantage of both ortho- and peri-substitution of Nap/Ace-substituted phosphine oxides. The synthetic method allows diversifying the polycyclic aromatic platform (Nap and Ace) as well as the Si substituents ( $\mathrm{Me}$ and $\mathrm{Ph}$ ). Despite a strong steric congestion, the $\mathrm{P}$-atom remains reactive toward oxidation or coordination. In particular, Au(I) complex could be prepared. All the compounds display absorption/luminescence in the UV-Vis range. Surprisingly, the P-trivalent derivatives display unexpected luminescence in the green in solidstate.
\end{abstract}

\section{Introduction}

Ortho-metalations belong to the Complex-Induced Proximity Effect based reactions and are widely used in organic synthesis.[1] Various functional groups (ether, amine, amide, ester, etc.), called the directing group, are used to orientate the metalation. However, heavier element containing functional groups such as phosphine oxides or phosphonates can also be used. ${ }^{[2]}$ For example, the use of ortho-lithiation on phosphinamide can lead to the synthesis of unprecedented heterocycles such as the $P$, Si containing 6-membered ring B (Figure 1). ${ }^{[2 d]}$ PeriSubstitution is a double substitution in positions 1 and 8 of naphthalene (Nap) (or acenaphthene (Ace)) (Figure 1b) . ${ }^{[3]}$ Unique geometric constraints are imposed to the substituents connected to these positions, which are even closer than ortho-substitution. Such molecular engineering has been recently used to stabilize reactive species featuring main group elements (B, $P, A s$ etc). ${ }^{[4]}$ Furthermore, the proximity between the peri-substituent offers the possibility of specific reactivity leading to the design novel heterocycles such as $P$, Si heterocycle $\mathbf{D}$ (Figure 1$).{ }^{[5,6]}$ During our study of multi-heteroatom-containing fluorophores, ${ }^{[7]}$ we noticed a specific reactivity of (8bromonaphthalen-1-yl)diphenylphosphine oxide $\mathbf{E}^{[8]}$ with silanes: we observed a sequence of ortho and perilithiation followed by intramolecular cyclization of a nine-membered ring $\mathbf{F}$ (Figure 1) through the formation of a disiloxane bridge. In this article, we present the straightforward synthesis of this unconventional heterocyclic platform, its reactivity, a detailed structural analysis and a study of its peculiar luminescent properties.

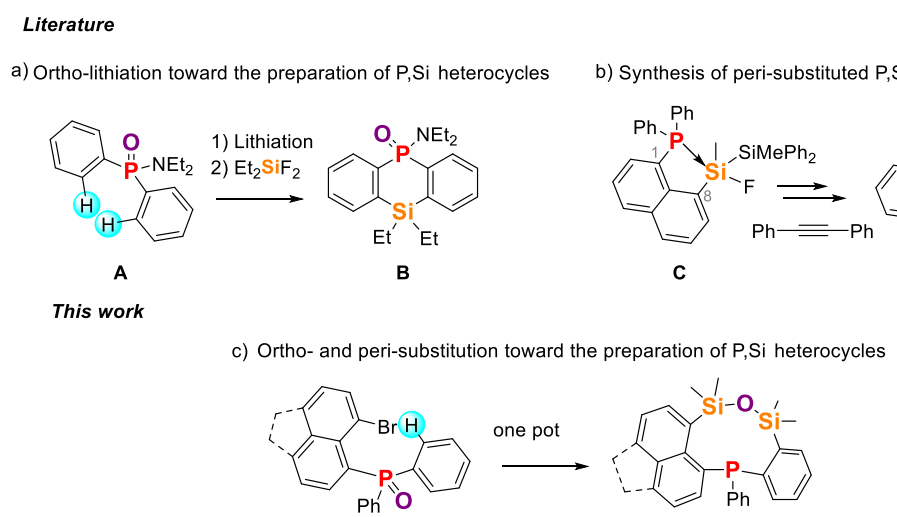

Figure 1: Examples of ortho-substitution (a) ${ }^{\mathrm{E}}$ and peri-substitution (b) toward the synthesis of P,Si heterocycles and strategy used in this work (c). 


\section{Results and discussion}

\section{Synthesis}

During our study of the reactivity of (8-bromonaphthalen-1-yl)diphenylphosphine oxide (Scheme 1), ${ }^{[8]}$ we observed that the lithiation of $\mathbf{1}$ followed by quenching with chlorodimethylsilane does not lead to the expected perisubstituted silane-phosphine oxide but to a peri-substituted Nap featuring a nine-membered ring incorporating a phosphine and a disiloxane bridge (Compound 3, Scheme 1). This unexpected compound was unambiguously characterized by multinuclear NMR, mass spectrometry and X-ray diffraction (Scheme 1, for full X-ray diffraction study and comparison, see below). At this point it is worth noting that during this sequence, a second $\mathrm{Si}$-atom has been introduced in ortho-position of the $P=0$ fragment and the $P$ atom is reduced from $\sigma^{4}, \lambda^{5}-P$ to $\sigma^{3}, \lambda^{3}-P$ (see postulated mechanism below). ${ }^{[9]}$ Careful tuning of the reaction conditions (2.2 eq. of BuLi and $\mathrm{HSiMe}_{2} \mathrm{Cl}$ ) allowed to optimize the yield of $\mathbf{3}$ to $55 \%$. Such synthetic method also efficiently works with Ace platform (4, Scheme 1).<smiles>O=P(c1ccccc1)(c1ccccc1)c1ccc2c3c(ccc(Br)c13)CC2</smiles>

Bridge:

1: none

$2: \mathrm{CH}_{2}-\mathrm{CH}_{2}$
1) $n$-BuLi (2.2 eq)

$-80^{\circ} \mathrm{C}, \mathrm{Et}_{2} \mathrm{O}, 1 \mathrm{~h}$

2) $\mathrm{HSiMe}_{2} \mathrm{Cl}$ (2.2 eq)

$-80^{\circ} \mathrm{C}$ to $\mathrm{rt}$

$\mathrm{Et}_{2} \mathrm{O}, 12 \mathrm{~h}$

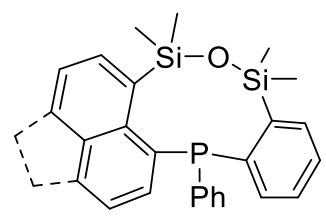

$3(55 \%)$

$4(53 \%)$

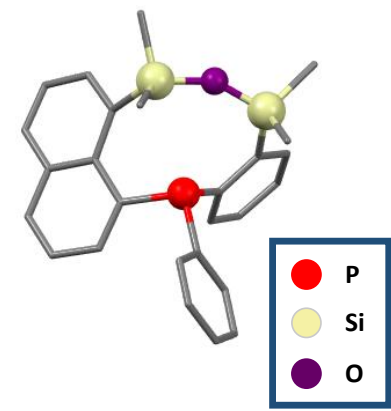

Scheme 1: Synthesis of 3-4 and X-ray structure 3

When bulkier diphenylchlorosilane is used as electrophile, the reaction stops at the silane-silanol intermediates 5-6 (Scheme 2) both with Nap and Ace platforms, probably due to the steric hindrance at the Si-atoms. In particular, the characterization of 6 (including X-ray diffraction, Scheme 2) unambiguously proves that the siloxane is formed on the peri-substituted Si-atom. The disiloxane formation could finally be obtained upon refluxing 5-6 in toluene to afford the cyclic derivatives 7-8.

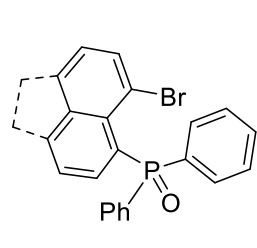

Bridge 1: none 2: $\mathrm{CH}_{2}-\mathrm{CH}_{2}$

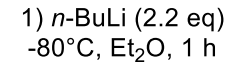

2) $\mathrm{HSiPh}_{2} \mathrm{Cl}(2.2 \mathrm{eq})$

$-80^{\circ} \mathrm{C}$ to rt, $\mathrm{Et}_{2} \mathrm{O}, 12 \mathrm{~h}$

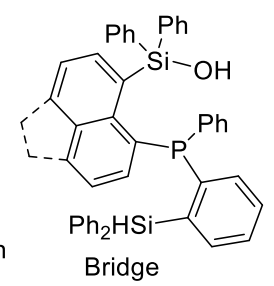

5: none $(18 \%)$

6: $\mathrm{CH}_{2}-\mathrm{CH}_{2}(38 \%)$

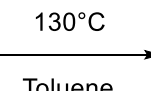

Toluene
2 days

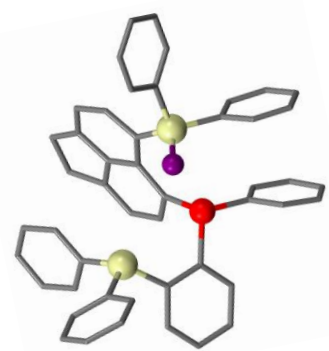

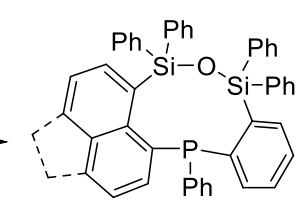

Bridge

7: none $(99 \%)$

8: $\mathrm{CH}_{2}-\mathrm{CH}_{2}(99 \%)$

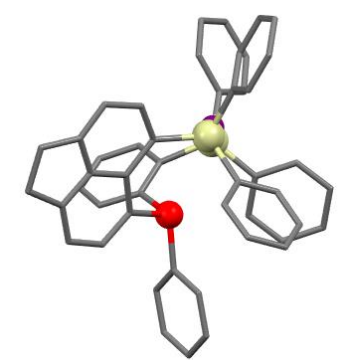

Scheme 2: Synthesis of 7-8 and X-ray structure of intermediate $\mathbf{6}$ and compound $\mathbf{8}$

Such reaction pathway can be explained (Scheme 3). The 2.2 eq of BuLi allow performing the expected Li-halogen exchange but also an ortho-lithiation on the phenyl ring connected to the phosphine oxide (II, Scheme 3). Such dilithiated derivatives is then quenched by chlorodimethysilane to afford III. The phosphine oxide moiety of III was in situ deprotected by the peri-substituted silane function ${ }^{[10]}$ to afford the mixed silane-silanol IV. The fact that the 
reduction is performed by the peri-substituted silane is evidenced by the characterization of intermediate 6 (Scheme 2). Finally, the disiloxane bridge of $\mathbf{V}$ is formed in the last step, either spontaneously $(\mathbf{3 , 4})$ or upon heating $(\mathbf{7 , 8})$.

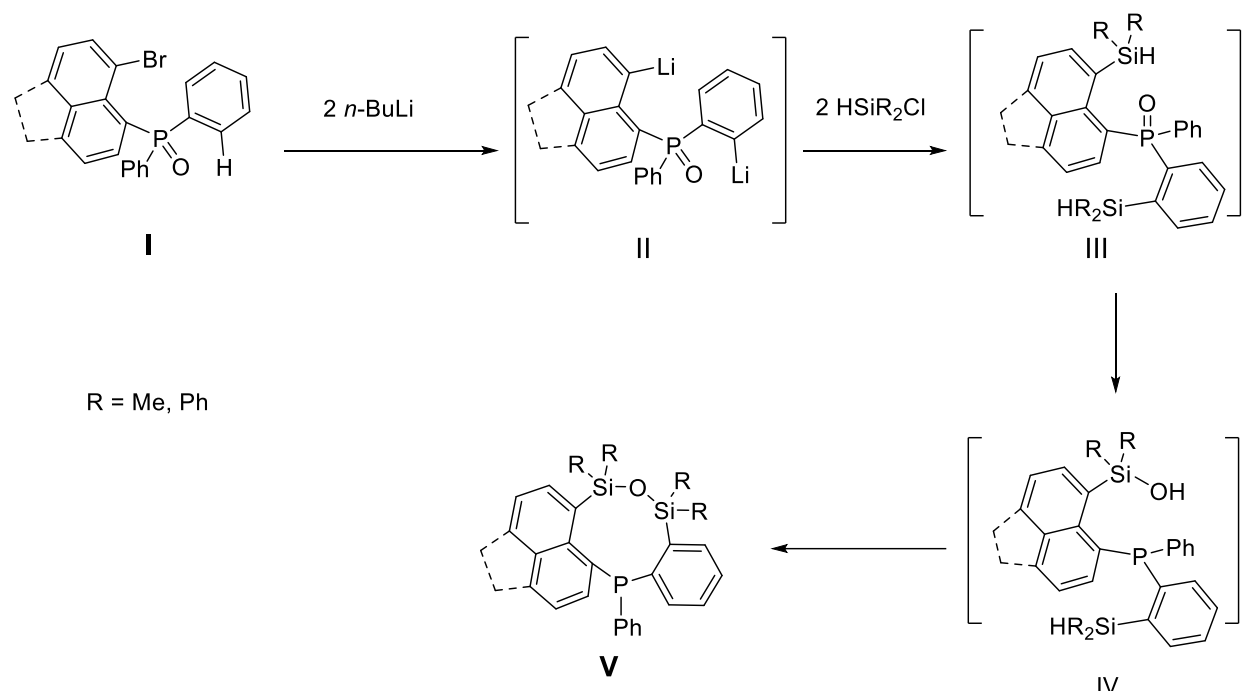

Scheme 3: postulated mechanism based on experimental observations

In short, a family of 4 cyclic phosphine-disiloxane featuring peri-substituted naphthyl scaffolds could be prepared in a very straightforward manner. They were all characterized by multinuclear NMR, mass spectrometry and X-ray diffraction. They display excellent air-stability both in solution and in solid, as well as good thermal stability $\left(\operatorname{Td}_{10}(\mathbf{4})\right.$ $=306^{\circ} \mathrm{C}$.

Phosphines are known to display a rich reactivity toward oxidant, electrophile or metallic ions. However, the $\mathrm{X}$-ray structures of 3,4 and 8 reveal that the lone pair of the P points toward the disiloxane bridge (Schemes 1,2), which can explain the excellent air stability of the compound. Nethertheless, the reactivity of the P-atom could be used and 3-4, 7-8 were quantitatively oxidized using $\mathrm{H}_{2} \mathrm{O}_{2}$ to afford $3^{\circ}, 4^{\circ}, 7^{\circ}$ and $4^{\circ}$ (scheme 4). Finally, the coordination ability these heterocycles was evaluated using of $\mathbf{3}$ as prototype compound. The $\sigma^{3}, \lambda^{3} \mathrm{P}$-atom behaves as a classic two-electrons P-donor toward Au' as evidenced by the formation of complex $3^{\mathrm{Au}}$ (Scheme 4).<smiles></smiles>

$\mathrm{Cl}$

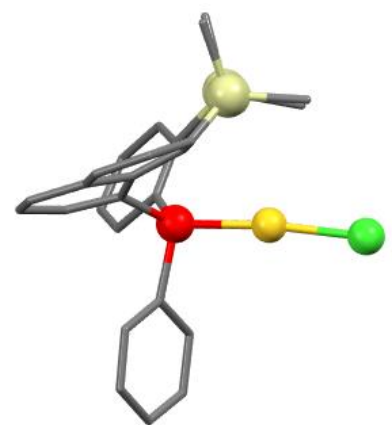<smiles></smiles>

Bridge / R :

$3:$ none / Me

$4: \mathrm{CH}_{2}-\mathrm{CH}_{2} / \mathrm{Me}$

7: none / $\mathrm{Ph}$

$8: \mathrm{CH}_{2}-\mathrm{CH}_{2} / \mathrm{Ph}$

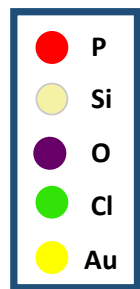

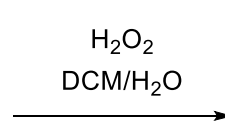

$\mathrm{rt}, 2$ days<smiles>[R][Si]1([R])Cc2cc(P(=O)(O)c3ccccc3)c3c4c-3ccc(c24)[Si]([R])([R])O1</smiles>

$3^{\circ}(100 \%)$

$4^{\circ}(99 \%)$

$7^{\circ}(100 \%)$

$8^{\circ}(99 \%)$

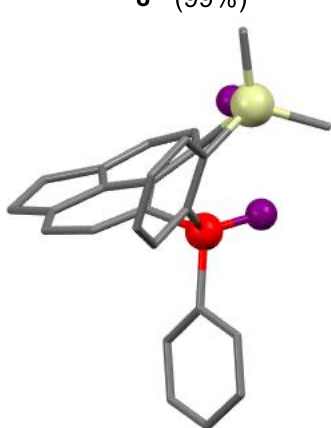

Scheme 4: Synthesis of $3^{\circ}-4^{\circ}, 7^{\circ}-8^{\circ}, 3^{\mathrm{Au}}, \mathrm{X}$-ray structure of $4^{\mathrm{O}}$ and $\mathbf{3}^{\mathrm{Au}}$

In conclusion, a family of cyclic phosphine-disiloxane featuring peri-substituted naphthyl scaffolds have been prepared and fully characterized. The synthetic method allows introducing different naphthyl platforms (Nap and Ace) and Si 
substituents ( $\mathrm{Me}$ and $\mathrm{Ph}$ ). The $\mathrm{P}$-atom remains reactive (oxidation, coordination) despite a highly sterically hindered scaffold.

\section{Structural properties}

Six heterocyclic compounds $\left(\mathbf{3}, 4,4^{\circ}, \mathbf{8}, 8^{\circ}\right.$ and $\left.\mathbf{3}^{\mathrm{Au}}\right)$ could be crystallized. A full crystallographic data study and comparison within the family is thus possible (Table 1). A detailed inspection will be performed on $\mathbf{3}$, then the general trend in the entire family will be discussed. 3 crystallizes in the P 21/c space group and the unit cell is composed by a racemic mixture of two enantiomers (the $\mathrm{P}$ atom in the molecule is stereogenic). The chemical structure of $\mathbf{3}$ is highly distorted due to the steric congestion to accommodate the trigonal $\mathrm{P}$-atom, the nine-membered heterocycle and peri-substituents (Figure 2). The P-C bond lengths and angles are classical for phosphanes $\left(1.83<\mathrm{d}_{\mathrm{P}-\mathrm{C}}<1.84 \AA\right.$ ) , as well as the Si-C distances $\left(1.90 \AA<\mathrm{d}_{\mathrm{Si}-\mathrm{C}}<1.92\right.$ $\AA$ ) et $\mathrm{Si}-\mathrm{O}\left(1.63 \AA<\mathrm{d}_{\mathrm{Si}-\mathrm{O}}<1.64 \AA\right.$ ) (Table 1$)$. The nine-membered ring display a boat-like conformation with equatorial position for the exocyclic P-Ph substituent (Figure $1 \mathrm{c})$. Consequently, the P-lone pair points toward the disiloxane bridge $\left(d_{P_{-} o}=3.181\right.$

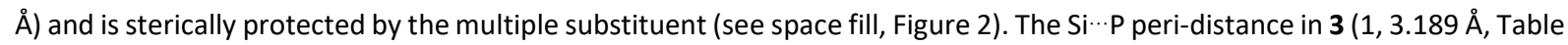
1 ) is indicative for predominantly repulsive interactions, as previously observed by Beckmann et al on acyclic Ace perisubstituted with phosphine and silane. ${ }^{6 a}$ Finally, the Nap is also distorted from planarity (Table 1) due to the presence of bulky substituent in peri-position. In the packing, $\pi$-dimers composed of the two enantiomers are observed in the solid-state (Figure 4).
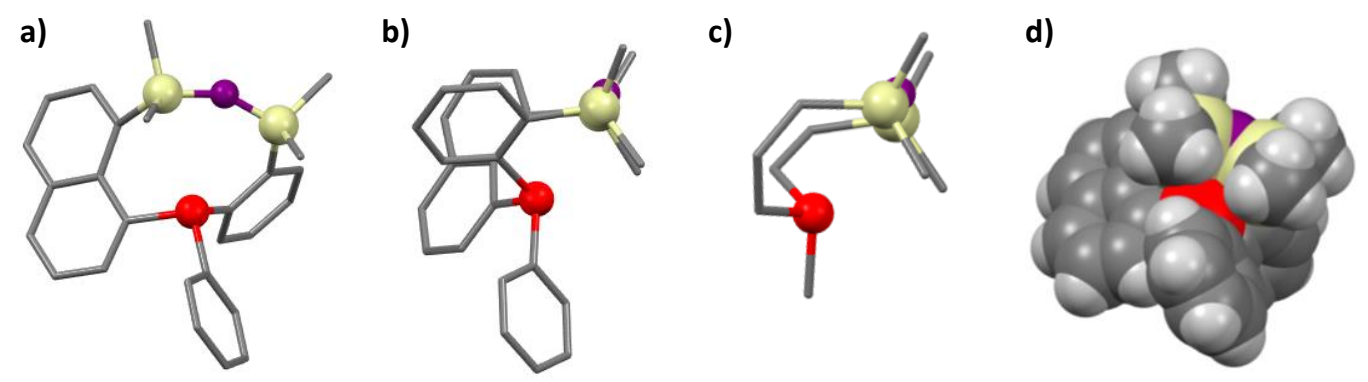

Figure 2: $(a, b)$ Different views of the crystallographic structure of 3, (c) zoom on the nine-membered ring (substituents omitted for clarity) and (d) space fill representation of $\mathbf{3}$

When Nap is replaced by Ace (4), most of the parameters remain valid (Table 1). Surprisingly, the presence of the Ph substituents on the $\mathrm{Si}$ in $\mathbf{8}$ has only a minor impact on the structural parameters (Figure 3). Upon oxidation, the ninemembered ring shape is altered due to the repulsion between the $\mathrm{P}=\mathrm{O}$ bond with the disiloxane bridge on one side, and the peri-substituted Si on the other one. Consequently, the P-Si peri distance increases as well as the distortion on the Nap/Ace platform (Figure 3 and Table 1). Such observations are even more pronounced upon coordination of the Au' (Figure 3 and Table 1) Indeed, a stronger deformation is induced by the quasi-linear P-Au-Cl fragment (P-Au-Cl: $\left.173.1^{\circ}\right)$. In the packing, the effects of substituent are almost impossible to rationalize as Nap-Nap $\pi$-dimers are observed for $\mathbf{3}$ (Figure 4), $4, \mathbf{8}, \pi$-columns through Ace-Ace interactions for $4^{\circ}$ (Figure 4), while no clear interaction is found for $8^{\circ}$ and $3^{\mathrm{Au}}$.

a)

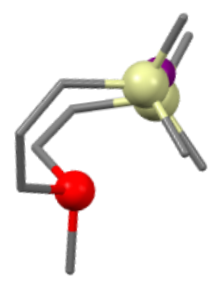

3 b)

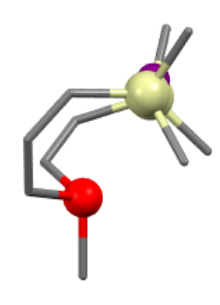

8 c)

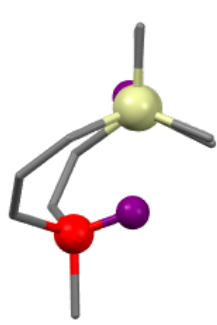

$8^{\circ}$ d)

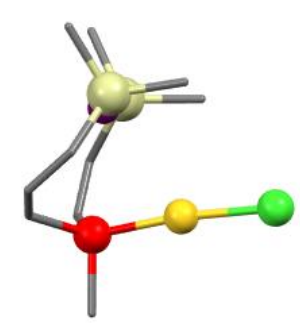

$3^{\mathrm{Au}}$

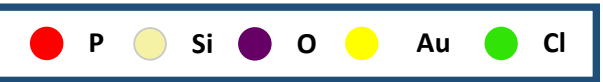

Figure 3: Zooms on the nine-membered ring (substituents omitted for clarity) of (a) 3 , (b) 8 , (c) $8^{\circ}$ and (d) $3^{\mathrm{Au}}$ 

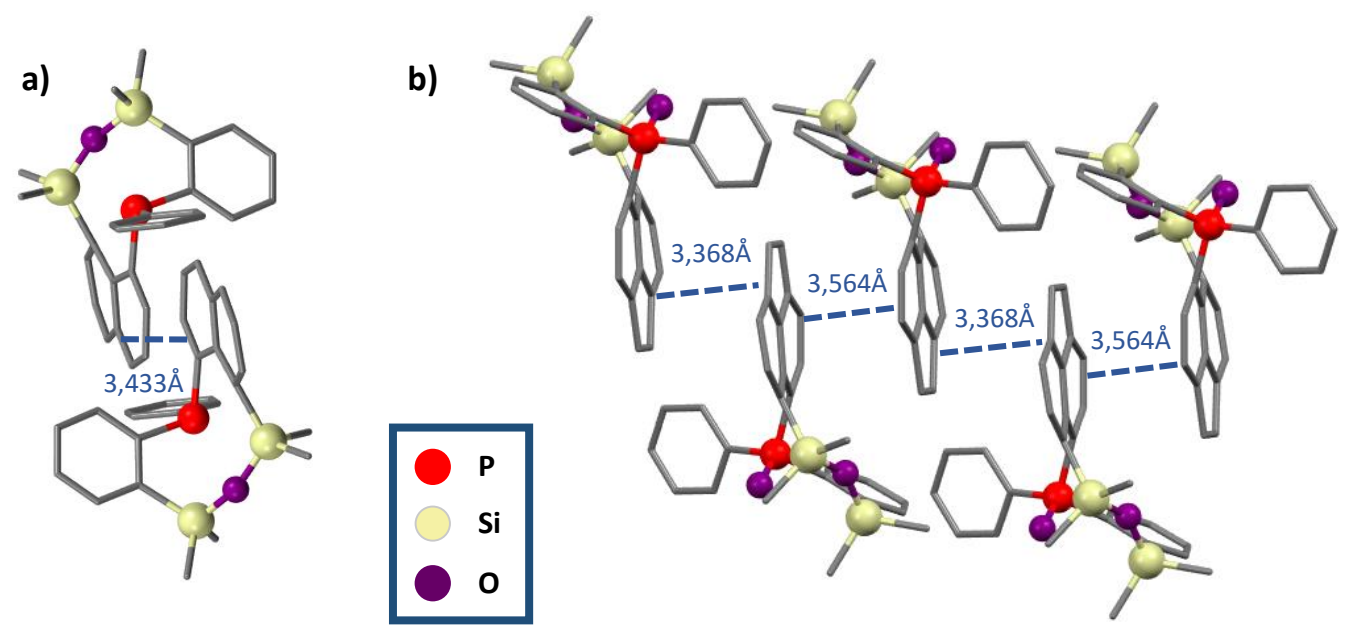

Figure 4: Intermolecular interactions observed in the packing of (a) 3 and (b) $4^{\circ}$

Table 1: Crystallographic data

\begin{tabular}{|c|c|c|c|c|c|c|}
\hline & 3 & 4 & 8 & $4^{\circ}$ & $8^{\circ}$ & $3^{\mathrm{Au}}$ \\
\hline $\mathrm{P}-\mathrm{C}_{1}(\AA ̊)$ & $1.829(2)$ & $1.835(2)$ & $1.830(4)$ & $1.811(2)$ & $1.801(2)$ & $1.821(8)$ \\
\hline $\mathrm{P}-\mathrm{C}_{5}(\AA)$ & $1.835(2)$ & $1.839(1)$ & $1.829(4)$ & $1.817(3)$ & $1.820(2)$ & $1.829(7)$ \\
\hline$C_{1}-C_{2}(\AA)$ & $1.435(3)$ & $1.445(2)$ & $1.433(6)$ & $1.441(4)$ & $1.438(2)$ & $1.440(1)$ \\
\hline $\mathrm{C}_{2}-\mathrm{C}_{3}(\AA)$ & $1.455(3)$ & $1.452(2)$ & $1.450(7)$ & $1.439(4)$ & $1.449(3)$ & $1.440(1)$ \\
\hline $\mathrm{C}_{3}-\mathrm{Si}_{1}(\AA)$ & $1.921(2)$ & $1.897(2)$ & $1.878(5)$ & $1.887(2)$ & $1.893(2)$ & $1.890(1)$ \\
\hline $\mathrm{Si}_{1}-\mathrm{O}(\AA)$ & $1.641(2)$ & $1.639(1)$ & $1.629(2)$ & $1.632(2)$ & $1.624(1)$ & $1.642(5)$ \\
\hline $\mathrm{O}-\mathrm{Si}_{2}(\mathrm{~A})$ & $1.637(2)$ & $1.634(1)$ & $1.625(3)$ & $1.627(2)$ & $1.624(1)$ & $1.626(6)$ \\
\hline $\mathrm{Si}_{2}-\mathrm{C}_{4}(\AA)$ & $1.897(2)$ & $1.890(1)$ & $1.879(6)$ & $1.886(3)$ & $1.887(2)$ & $1.886(9)$ \\
\hline $\mathrm{C}_{4}-\mathrm{C}_{5}(\AA)$ & $1.415(3)$ & $1.410(2)$ & $1.401(6)$ & $1.414(3)$ & $1.418(2)$ & $1.410(1)$ \\
\hline $\mathrm{C}_{1}-\mathrm{P}-\mathrm{C}_{5}\left({ }^{\circ}\right)$ & $103.00(1)$ & $104.72(7)$ & $101.00(2)$ & $106.20(1)$ & $105.50(8)$ & $106.40(4)$ \\
\hline \multicolumn{7}{|c|}{ peri distances } \\
\hline $\mathrm{P} \cdots \mathrm{Si}$ & 3.189 & 3.242 & 3.199 & 3.687 & 3.575 & 3.789 \\
\hline \multicolumn{7}{|c|}{ Intracycle distances } \\
\hline$P \cdots O$ & 3.181 & 3.147 & 3.097 & 3.176 & 3.313 & 2.988 \\
\hline
\end{tabular}




\section{Optical properties}

$\pi$-conjugated P-heterocycles and Si-heterocycles display rich optical properties, ${ }^{[11]}$ the UV-vis absorption and fluorescence properties of 3-8 (resp $\left.3^{\circ}-\mathbf{8}^{\circ}\right)$ were thus investigated in diluted dichloromethane $\left(C=10^{-5} \mathrm{M}\right)$ (table 2 ). They all display absorption bands in the UV characteristic of substituted Nap ${ }^{[12]}$ and the effect of molecular engineering remain modest. For example, 4 displays absorptions bands with moderate extinction coefficient at $\lambda_{\max }(308 \mathrm{~nm})$. The polycyclic aromatic platform has a small influence on the absorption as the UV-vis absorption of the Ace heterocycles is slightly red-shifted compared to their Nap analogues (Table 2 and Fig S19). The oxidation has the opposite effect as the $\sigma^{4}, \lambda^{5}$-P-derivatives display a blueshifted absorption compared to their $\sigma^{3}, \lambda^{3}$-P-analogues (Table 2 and Fig 5 ). This can be explained by the stronger distortion of the $\pi$-system of the Nap/Ace induced by the presence of the $P=O$ fragment (Table 2).

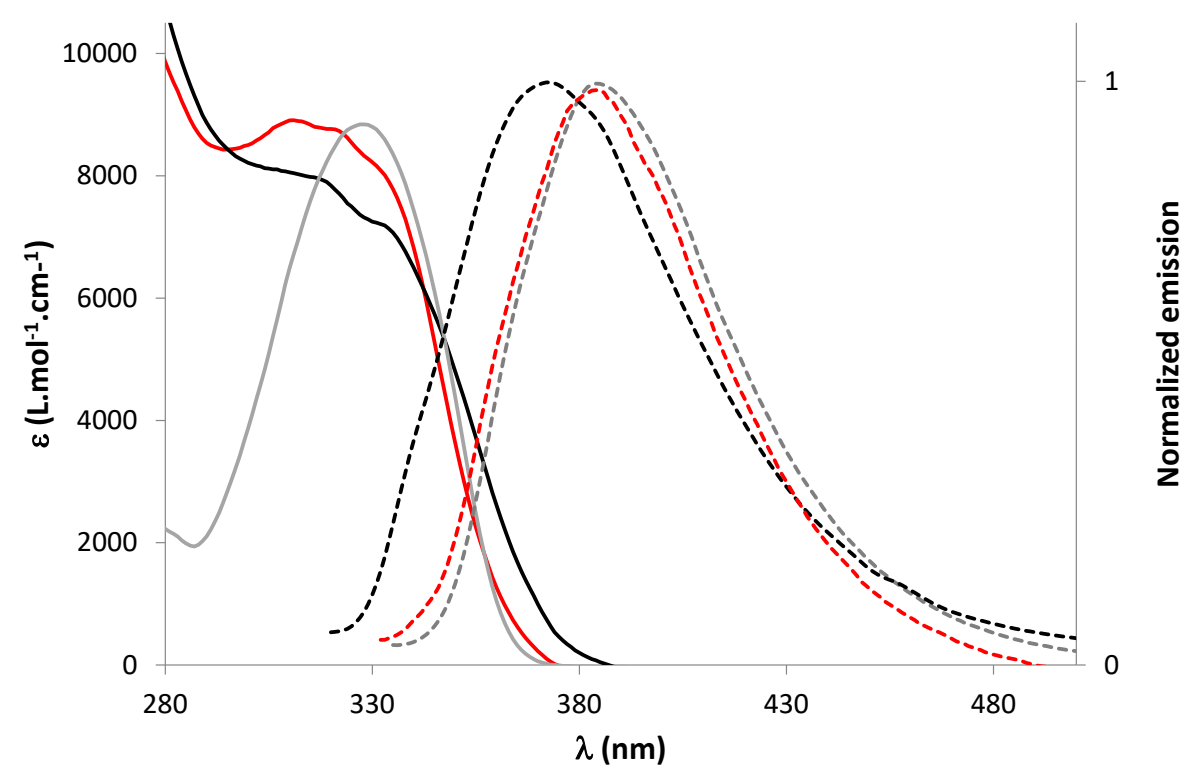

Figure 5: Absorption (solid line) and emission (dotted line) spectra of $\mathbf{4}$ (red), 8 (black), $\mathbf{4}^{\circ}$ (grey) in diluted DCM

The fluorescent properties of the heterocycles are more peculiar. While the P-trivalent derivatives featuring a Nap platform, are not luminescent in solution, all the other compounds display emission in the near UV, characteristic of substituted Nap/Ace. ${ }^{[12]}$ Apart from $\mathbf{4}^{\circ}$, the luminescence quantum yields are modest (table 2). The effect of the substituents on the emission wavelength is also rather limited. While all the heterocycles have modest luminescent properties in diluted solutions, crystalline samples of P-trivalent 3-4 and 7-8 display unexpected greenish luminescence (for example $\lambda_{\text {emsolid (4) }}$ $=504 \mathrm{~nm}$ while $\lambda_{\text {emliq }}(4)=381 \mathrm{~nm}$ ) with quantum yields between $9 \%$ and $32 \%$ (Figure 6 and Table 2). Such important redshift of 3-4 and 7-8 is not observed for pentavalent P-cycles which display weak solid-state luminescence in the spectral range of their emission in diluted solution (for example $\lambda_{\text {em }}$ solid $\left(4^{\circ}\right)=414 \mathrm{~nm}$ while $\lambda_{\text {em }}$ liq $\left(4^{\circ}\right)=382 \mathrm{~nm}$, see Figure S20). Such unexpected red-shifted solid-state emission can have two main origins: specific aggregate formation or triplet emission (phosphorescence). ${ }^{[13,14]}$ Time-resolved fluorescence measurements allowed to rule out the possibility of phosphorescence as all compounds display emission lifetime in the range of the ns, typical of fluorescent materials (see Figure S21-24). The study of the packing in the crystals did not allow to clarify the presence of specific interactions that would favour these observations, as some of these compounds form $\pi$-dimers but other don't. Finally, when the compound is isolated under the form of an amorphous material or diluted in PMA matrix ( $5 \%$ weight), no green luminescence could be observed, which clearly emphasizes the role of intermolecular interaction in the solid state, even if the inspection of X-Ray data did not allow to unravel their nature. 


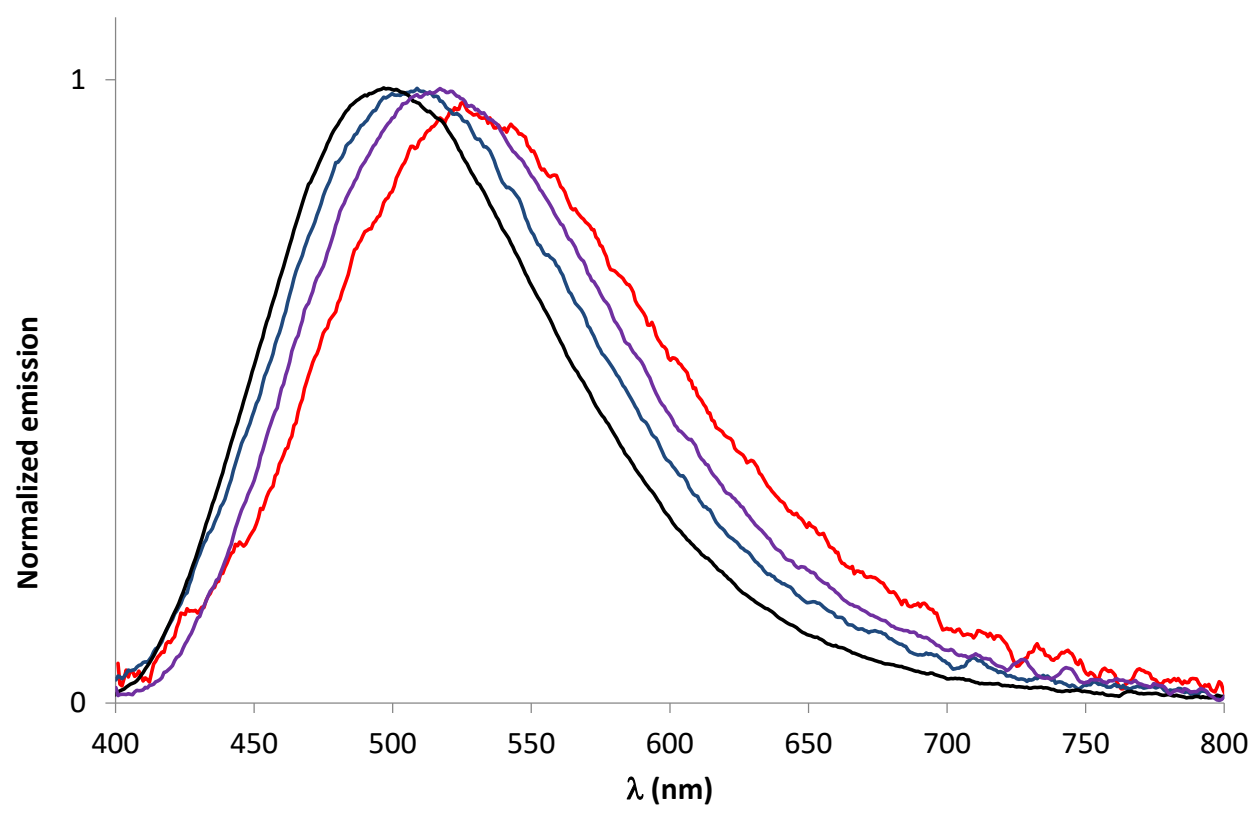

Figure 6: Emission spectra in solid-state of 3 (blue), 4(red), 7 (purple) and 8 (black)

Table 2: Photophysical data.

\begin{tabular}{|c|c|c|c|c|c|c|c|c|}
\hline Compound & $\begin{array}{l}\lambda_{\mathrm{abs}}{ }^{[\mathrm{a}]} \\
(\mathrm{nm})\end{array}$ & $\begin{array}{c}\varepsilon_{\max } \\
\left(\text { L. }^{-1} \mathrm{fol}^{-1} . \mathrm{cm}^{-1}\right)^{[\mathrm{a}]}\end{array}$ & $\begin{array}{l}\lambda_{0-0}{ }^{[a]} \\
(\mathrm{nm})\end{array}$ & $\begin{array}{c}\lambda_{\text {em }}^{\text {liq [a] }} \\
(\mathrm{nm})\end{array}$ & $\begin{array}{c}\lambda_{\text {em }}^{\text {solid [b] }} \\
(\mathrm{nm})\end{array}$ & $\begin{array}{l}\text { Stokes shift } \\
(\mathrm{cm}-1)^{[a]}\end{array}$ & $\Phi_{\text {liquid }}{ }^{[b]}$ & $\Phi_{\text {solid }}{ }^{[b]}$ \\
\hline 3 & 322 & 7400 & - & - & 495 & - & - & 0.32 \\
\hline 4 & 308 & 8900 & 350 & 381 & 504 & 6200 & $<0.01$ & 0.09 \\
\hline 7 & 327 & 7500 & - & - & 498 & - & - & 0.14 \\
\hline 8 & 309 & 8000 & 345 & 371 & 495 & 5400 & $<0.01$ & 0.11 \\
\hline $3^{\circ}$ & 310 & 7700 & 328 & 347 & 418 & 3400 & 0.07 & 0.07 \\
\hline $4^{\circ}$ & 327 & 8900 & 353 & 382 & 414 & 4400 & 0.60 & 0.08 \\
\hline $7^{\circ}$ & 309 & 8200 & 329 & 353 & 398 & 4000 & 0.05 & 0.05 \\
\hline $8^{\circ}$ & 322 & 8000 & 350 & 386 & 420 & 6600 & 0.06 & 0.01 \\
\hline
\end{tabular}

[a] Measured in diluted $\mathrm{CH}_{2} \mathrm{Cl}_{2}\left(10^{-5} \mathrm{M}\right)$. [b] Measured in calibrated integration sphere.

\section{Conclusion}

In conclusion, a full family of cyclic phosphine-disiloxane featuring peri-substituted naphthyl and acenaphtyl scaffolds have been prepared and fully characterized. This straightforward synthesis takes advantage of both ortho- and perisubstitution of Nap/Ace-substituted phosphine oxides. The synthetic method allows introducing various polyaromatic platforms (Nap and Ace), various Si substituents (Me and Ph). Despite a strong steric congestion, the $\mathrm{P}$-atom remains reactive (oxidation, coordination). In particular, $\mathrm{Au}(\mathrm{I})$ complex $3^{\mathrm{Au}}$ could be prepared. All the compounds display absorption/luminescence in the UV-vis. Surprisingly, the P-trivalent derivatives display unexpected green luminescence in the solid-state. Finally, given to their easy synthesis, these unconventional heterocycles can be further used to design solid-state luminophore or cavity-shaped ligands for application in supramolecular catalysis. ${ }^{[15]}$ 


\section{Acknowledgements}

This work is supported by the Ministère de la Recherche et de l'Enseignement Supérieur, the CNRS, the Région Bretagne, the French National Research Agency (ANR Heterographene ANR-16-CE05-0003-01). Y. Molard, G. Taupier (Scanmat-UMS 2001) and C. Poriel (ISCR) are thanked for PLQY measurements.

Keywords: Heterocycles; P-chemistry; Si-Chemistry; Fluorescence.

TOC
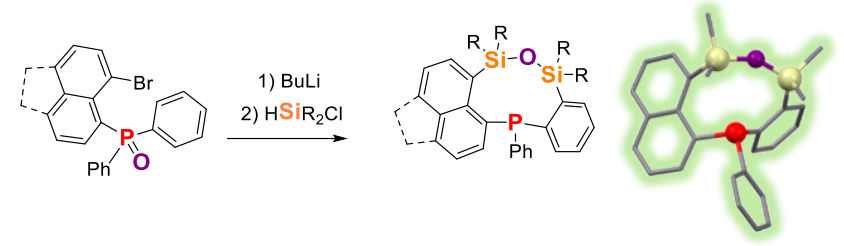

A family of cyclic phosphine-disiloxane featuring peri-substituted naphthyl(Nap)/acenaphthyl(Ace) scaffolds has been prepared. This straightforward synthesis takes advantage of both ortho- and peri-substitution of Nap/Acesubstituted phosphine oxides. The synthetic method allows diversifying the polycyclic aromatic platform and the Si substituents. Despite some steric congestion, the P-atom remains reactive. In particular, Au(I) complex could be prepared. Surprisingly, the P-trivalent derivatives display unexpected luminescence in the green in solid-state.

[1] M. C. Whisler, S. MacNeil, V. Snieckus, P. Beak, Angew. Chem. Int. Ed. 2004, 43, 2206-2225.

[2] a) B. Schaub, T. Jenny, M. Schlosser, Tetrahedron Lett. 1984, 25, 4097-4100; b) W. Michael and M. Kurt, Bull. Chem. Soc. Jap. 2003, 76, 1233-1244; c) M. A. del Águila-Sánchez, Y. Navarro, J. García López, G. P. Guedes, F. López Ortiz, Dalt. Trans. 2016, 45, 2008-2022.d) H. Tsuji, S. Komatsu, Y. Kanda, T. Umehara, T. Saeki, K. Tamao, Chem. Lett. 2006, 35, 758-759.

[3] P. Kilian, F. R. Knight, J. D. Woollins, Chem. Eur. J. 2011, 17, 2302-2328.

[4] a) B. A. Chalmers, M. Bühl, K. S. Athukorala Arachchige, A. M. Z. Slawin, P. Kilian, J. Am. Chem. Soc. 2014, 136, 6247-6250. b) B. A. Surgenor, M. Bühl, A. M. Z. Slawin, J. D. Woollins, P. Kilian, Angew. Chem. Int. Ed. 2012, 51, 10150-10153. C) M. Devillard, R. Brousses, K. Miqueu, G. Bouhadir, D. Bourissou, Angew. Chem. Int. Ed. 2015, 54, 5722-5726. d) A. J. Rosenthal, M. Devillard, K. Miqueu, G. Bouhadir, D. Bourissou, Angew. Chem. Int. Ed. 2015, 54, 9198-9202. e) M. Olaru, R. Kather, E. Hupf, E. Lork, S. Mebs, J. Beckmann, Angew. Chem. Int. Ed. 2018, 57, 5917-5920.

[5] A. Toshimitsu, T. Saeki, K. Tamao, J. Am. Chem. Soc., 2001, 123, 9210-9211.

[6] For other P,Si peri-substituted Ace see: a) E. Hupf, E. Lork, S. Mebs, J. Beckmann, Organometallics 2015, 34, 3873-3887; b) E. Hupf, M. Olaru, C. I. Raţ, M. Fugel, C. B. Hübschle, E. Lork, S. Grabowsky, S. Mebs, J. Beckmann, Chem. Eur. J. 2017, 23, 10568-10579; c) E. Hupf, L. A. Malaspina, S. Holsten, F. Kleemiss, A. J. Edwards, J. R. Price, V. Kozich, K. Heyne, S. Mebs, S. Grabowsky, J. Beckmann, Inorg. Chem. 2019, 58, 16372-16378; d) S. Holsten, E. Hupf, E. Lork, S. Mebs, J. Beckmann, Dalton Trans. 2020, 49, 1731-1735.

[7] a) H. Chen, W. Delaunay, J. Li, Z. Wang, P.-A. Bouit, D. Tondelier, B. Geffroy, F. Mathey, Z. Duan, R. Réau, M. Hissler, Org. Lett. 2013, 15, 330-333. B) H. Chen, M. Denis, P.-A. Bouit, Y. Zhang, X. Wei, D. Tondelier, B. Geffroy, Z. Duan, M. Hissler, Appl. Sci. 2018, 8, 812. c) T. Delouche, A. Mocanu, T. Roisnel, R. Szűcs, E. Jacques, Z. Benkő, L. Nyulászi, P.-A. Bouit, M. Hissler, Org. Lett. 2019, 21, 802-806.

[8] T. Delouche, R. Mokrai, T. Roisnel, D. Tondelier, B. Geffroy, L. Nyulászi, Z. Benkő, M. Hissler, P.-A. Bouit, Chem. Eur. J. 2020, 26, 1856-1863.

[9] $\sigma$ represents the coordination number and $\lambda$ the valence of the P-atom

[10] E. Podyacheva, E. Kuchuk, D. Chusov, Tetrahedron Lett. 2019, 60, 575-582.

[11] a) T. Baumgartner, F. Jaekle, (Eds), Main Group Strategies toward Functional Hybrid Materials, 2018, John Wiley \& Sons (UK); b) M. Hissler, P. W. Dyer, R. Réau, Coord. Chem. Rev. 2003, 244, 1-44; c) D. Joly, P. A. Bouit, M. Hissler, J. Mater. Chem. C 2016, 4, 3686-3698. d) M. Grzybowski, M. Taki, K. Senda, Y. Sato, T. Ariyoshi, Y. Okada, R. Kawakami, T. Imamura, S. Yamaguchi, Angew. Chem. Int. Ed. 2018, 57, 10137-10141. 
[12] H. Maeda, T. Maeda, K. Mizuno, Molecules 2012, 17, 5108-5125.

[13] M. Baroncini, G. Bergamini, P. Ceroni, Chem. Commun. 2017, 53, 2081-2093.

[14] For specific example of $P, O, S i$ containing pi-systems featuring room temperature phosphorescence see: M. Shimizu, S. Nagano, T. Kinoshita, Chem. Eur. J. 2020, 26, 5162-5167.

[15] a) D. Sémeril, D. Matt, Coord. Chem. Rev. 2014, 279, 58-95b) F. Elaieb, D. Sémeril, D. Matt, M. Pfeffer, P.-A. Bouit, M. Hissler, C. Gourlaouen, J. Harrowfield, Dalton Trans. 2017, 46, 9833-9845. 